\title{
MACHINIMA IN EDUCATION FOR SECURITY AND SAFETY
}

\author{
Małgorzata Gawlik-Kobylińska ${ }^{1}$ \\ ${ }^{l}$ War Studies University, Command and Management Faculty, Warsaw, Poland
}

\begin{abstract}
Machinima, a video created in virtual environment, reveals a great potential for education. As a video, it visualizes dangerous situations and, as a task - it enables cooperation between learners on specific solutions concerning combating threats. Those advantages predestine machinima to the role of a didactic tool and an didactic activity used in either military or civilian education and training. It must be stressed that this kind of education concerns basically Polish solutions according to which specific issues on security and safety are taught at primary and secondary schools. Education for security and safety is also in the scope of interest of Polish civil and military universities. As a result, there is a need for research in this area and development of dedicated teaching programs, which include innovative solutions. One of the examples of the use such solutions is implementation of information and communication technologies in production of teaching materials. Or treat them as a didactic environment used to trigger students' activities. The article is of ascertainment-improvement character and it aims to analyze the role of machinima in education for security and safety, which nowadays seems to be underestimated and not fully recognized. The analysis will be supported with three case studies illustrating the implementation of machinima into curricula. Those case studies concern the activities conducted at the War Studies University in Warsaw, which were related to CreAting Machinima Empowers Live Online Language Teaching and Learning (CAMELOT)projectand the Defence Education EnhancementProgramme (DEEP) based on bilateral partnership cooperation programs between NATO and individual nations.
\end{abstract}

Keywords: machinima, education for security and safety, video, task-based approach

\section{INTRODUCTION}

There is no doubt that security and safety is a timeless value and is related to the condition of the existence and development of an individual (Kunikowski, 2000). Counteracting potential threats is a key task for all participants of the society. One of the forms of this counteraction relies on educating for security and safety (Pieczywok, 2012). This kind of education is aimed at civic education(cf. Pich et al. 2011,Węsierski et al 2013), military education (cf. Maciejewski et al. 2015), health (cf. Nijs et al. 2015, Klein, 2016), environmental education (cf. Maciejewski et al. 2009, Ulewicz et al. 2013, SobianowskaTurek et al. 2015, 2016) and communication (cf. Razzaque et al. 2015, Robinson-Mallett et al., 2015) as well as human functioning in the cyberspace (cf. Penzestadler et al., 2014). Moreover, it involves creating proper attitudes and values, gaining knowledge and skills in the area of countering various threats. In Poland this kind of education is compulsory since 2009 and it concerns primary and secondary schools (according to the Regulation of the Ministry of National Education of 28 August, 2009 on the implementation of safety and security education). It can be noted that this kind of education, so crucial for today's society undisturbed performance and functioning, is highly interdisciplinary and requires a specific attention to combine different areas of knowledge. Regarding the significance and nature of education for security and safety, educators should pay attention to its didactic process elements. Each component of the didactic chain should be well thought out, planned, and interspersed with engaging activities. One of the proposal for didactic activities from the area of security and safety is application of machinima in didactic process.
The article discusses the role of machinima as a teaching tool in the scope of education for security and safety. It is based on analysis of three case studies which refer to two different approaches to machinima: as a didactic material (video) and as a task.

\section{EDUCATION FOR SECURITY AND SAFETY}

In Poland, the subject education for security and safety (in Polish: edukacjadlabezpieczeństwa) is the result of an agreement between the Ministry of National Education and the Ministry of National Defense of the Republic of Poland. As it was mentioned above, it scope covers multifarious areas. To be specific, education for security and safety it concerns broadly defined civil defense, methods of protection against various hazards and preparation for dealing with disasters, first aid. It also involves typically military subjects, such as weapons types and military service rules, selected issues on international law of armed conflict and topography. Therefore, it is an essential part of both the educational process and preventive measures, primarily aimed at civic education, communication, and health and environmental education. It is also recognized as a necessary element of upbringing and preparation for living and working in modern conditions (Pieczywok, 2012). It is vital to state that the Polish authors (Siuda, 2001) enumerate different types of this kind education, for instance:

-education for military security - education and defense education - it aims at preserving the independence of the nation and the state and protection of human life and people in time of war;

-education for economic security - it is the formation of economic consciousness; 
-education for public safety - this is the shaping of legal consciousness and attitudes towards threats for public life; -education for psychosocial safety - this is shaping morality of societies and attitudes towards shaping the morality of society, as well attitudes towards vulnerability to psychosocial risks;

-education for environmental safety - it is a harmonious cohabitation of people with nature and shaping proecological behaviors.

To sum up. this kind of education has a wide scope and it covers all activities related to human well-being (physical, psychological, social, environmental).

\section{MACHINIMA}

Machinima is the art of making animated movies in a 3D virtual environment in real time (Marino, 2004, p.2) and as a neologism it combines machine, cinema, and animation. In this cinematographic genre, gamers or virtual world users become film directors, who decide on a genre, scenario, cast, setting. They can also create a desired mood by adding particular effects, soundtrack, transitions, or make the video more engrossing by adding interactions. Videos created in virtual reality gain popularity in the 90 . of the twentieth century. The first pieces of art were created in the environment of computer games. Therefore, machinima can be perceived as a medium which offers links to a comparative horizon that informs, changes, and fully participates in videogame culture (Krapp, 2010).Kelland, Morris, and Lloyd (2010) enumerate basic techniques of creating machinima. These are:

- relying on the game's AI to control most action (machinima is easy in production, however the action can be unpredictable due to the fact that AI-dependent results cannot be predictable),

- digital puppetry (machinima creators are virtual actors avatars - and each crew member controls a character in real-time, as in a multiplayer game),

- recamming (which builds on puppetry, actions are first recorded to a game engine's demo file format, not directly as video frames; moreover, machinimators can later manipulate the demo files to add cameras, tweak timing and lighting, as well as change the surroundings),

precise scripting of actions (scripting consists of giving precise directions to the game engine, but sometimes scripting capabilities may be limited or unavailable).

Those techniques of creating machinima creates a potential for its various concepts and genres.

A machinima or a set of machinima can be designed for the purpose of education for safety and security. Primarily, apart from a proper scenario, it requires the choice of a setting, avatars which can be provided by a 3D game or social platform such as Second Life (secondlife.com). It must be emphasized that creating and using 3D environment for safety and security specifically, is not a really new concept; these are numerous examples of virtual worlds concerning this topic (Le \& Park, 2012; Zhao \& Ye 2012; Fei\&Anbi 2011), and, as it could be expected, they do not concern military contexts only. From the perspective of Polish educational system underlying the value of teaching on security and safety, the use of thematic digital environments support two ways of machinima use: as a digital video (Weerasinghe\& Mathews, 2017) or as a task (Schneider, 2016).

\subsection{Machinima as a Video}

The simplest ways of creating videos rely on a storytelling monologue produced in situated learning contexts. In a digital environment, an actor is an avatar and the stage is provided by computer generated imagery. The camera used to record the action e is screen recording software, what makes the production highly cost-effective. Such a video can be easily disseminated to learners and teachers as videopodcasts (or vodcasts).

\section{Case Study 1}

The machinima When No Smoking really means No Smoking (a factory walk around looking out for safety issues) was produced within the CAMELOT Project (20132015) (camelotproject.eu). The video can be used as a teaching material for demonstrating inappropriate behaviours in the area of a factory. Apart from the conveyed message, it can be used for the purpose of the Content Language Integrated Learning (CLIL), which emphasizes the significance of combining language and the learned subject (Nikula\&Dafouz, 2016).

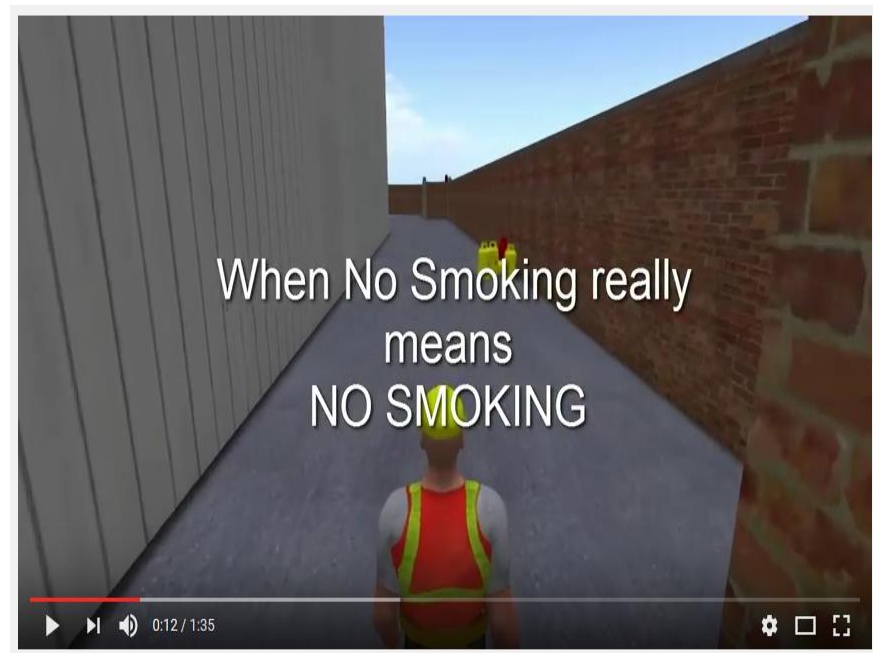

When No Smoking really means no smoking

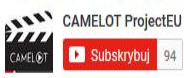

80 wyświetleń

Fig -1: Machinima When No Smoking really means NoSmoking

Source: https://www.youtube.com/watch?v=3a4tPpY36uc (30.06.2017).

\section{Case Study 2}

Another machinimaHow high is too high?, produced within the mentioned above CAMELOT project, illustrates inappropriate and risky behaviors that should be avoided 
while working at heights. The video was published in March 2015 and can serve as a didactic tool (simulation, painless learning on avatar's mistakes) supporting lessons on occupational health and safety issues (a triggering material for class discussion, recapitalization of a lesson). Similarly to the first video, it can also be used for CLIL lessons, during which students acquire vocabulary from this particular topic.

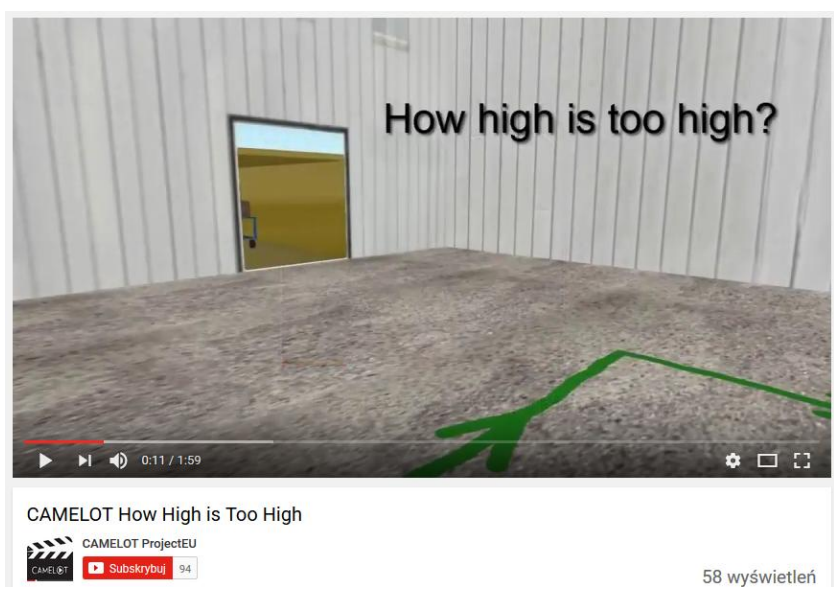

Fig -2: Machinima How high is too high?

Source: https://www.youtube.com/watch?v=3a4tPpY36uc $(30.06 .2017)$

The two examples indicate that creating machinima for the needs of education for security and safety requires primarily setting the objectives, then writing a scenario, and finally finding a setting, and preparing details for recording. Apart from those activities, both students and teachers needs to be familiar with digital environment and the software for recording the action. Digital skills and basis of filmmaking are crucial for achieving a satisfactory effect. Undoubtedly, a big advantage of such a video is low cost of production as all elements of the machinima are created digitally. However, it must be noted that the process of its production can be time consuming and demanding, especially when more than one avatar is engaged. Regardless those advantages and disadvantages, those videos can serve as versatile tools supporting traditional lessons.

\subsection{Machinima as a Task}

The task-based approach relies on engagement of students into a particular activity (individual or group). Although it has been initiated and popularized in the area of second language learning and teaching (Calverand Sheen, 2015), it can be adopted in education for safety and security. In this context, it means that creating machinima can be a task for a group of learners, who gain specific roles, such as: director, actor (with avatar), music composer, narrator, etc. As a team, they can create a video on an assigned topic. The task of creating machinima bring numerous advantages. Apart from engagement in the topic, students gain digital literacy and they are trained to cooperate. When such a cooperation is led in intercultural environment, they acquire intercultural skills in a natural way. What is important, the dynamism of learning becomes more intensified by bringing learners' minds and cognitive skills into play. Such a situation was observed during a workshopImmersiveLearning in Linguistic Educationorganized within NATO Education Enhancement Programme Ukraine (DEEP Ukraine), which was conducted at the National Defence University in Warsaw (13-17 of April 2015) (Poland ADL Partnership Lab official website, 2015). The objective of the workshop was to familiarize teachers and professors of English from fourdefence education institutions (Kyiv, Lviv, Kharkiv and Zhytomyr) with the issue of how to create machinima.They could acquire specific skills on how to create a video in a $3 \mathrm{D}$ environment to present their own narration. The assigned topic was coping with posttraumatic stress disorder, which was related to the political situation in Ukraine. The chosen setting was Psychological Health Islandon secondlife.com (The Virtual PTSD Experience, created by the US Department of Defense) and applied techniques involved digital puppetry and recamming.Machinima, created by workshop participants individually or collaboratively, was used for recording of stories and memories of individuals who retell their or other person's stories. In the stories are reflected emotional states, reactions to crisis situations happened in their home area.In this context machinima served as a documentary.

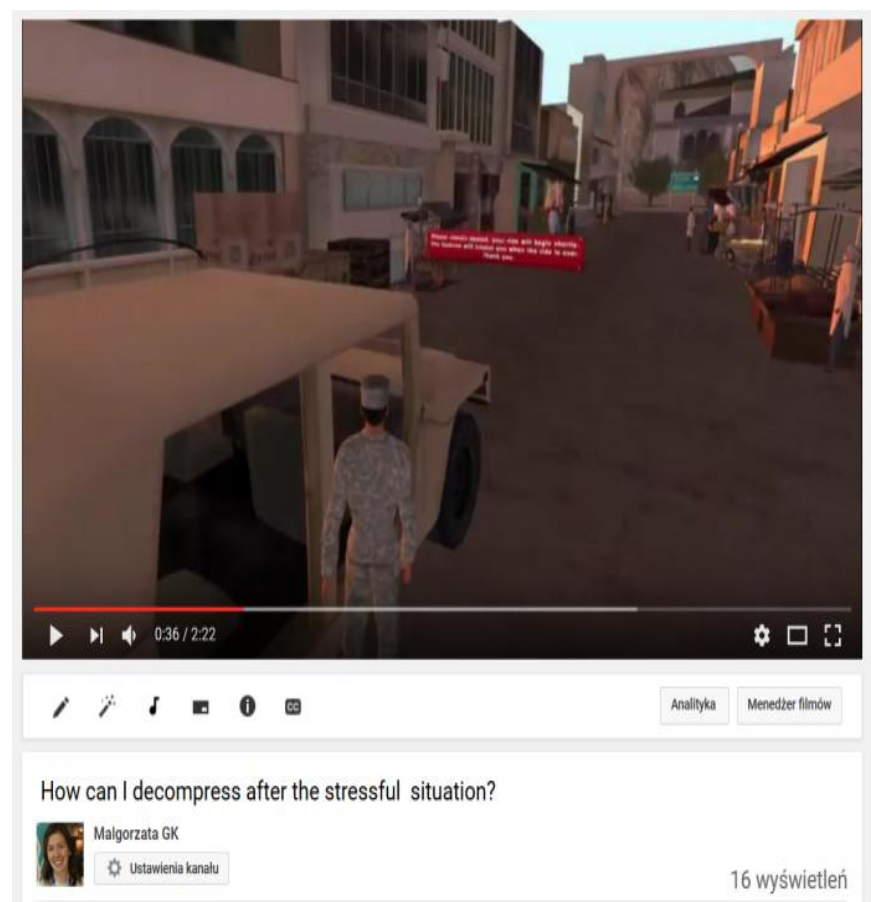

Fig -3: Machinima on posttraumatic stress disorder How can I decompress after the stressful situation

Source:

https://www.youtube.com/watch?v=JCfXLHH2LGE\&t=28s

Worth noticing was the fact that these stories were discussed in the event participants in order to avoid creating a legend. The discussion aimed to conduct a constructive analysis of the event and provide an opportunity of an answerwhat can be changed for the better. The cooperation of the group relied on a framework created on the basis of approach proposed by R. Ellis (2006) (Fig. 1). 
Table 1: A framework for designing task-based lessons

\begin{tabular}{|l|l|}
\hline $\begin{array}{l}\text { Lesson's } \\
\text { Phase }\end{array}$ & Activities \\
\hline Pre-task & $\begin{array}{l}\text { Framing of activity (giving } \\
\text { scenarios } \\
\text { Planning conducting certain } \\
\text { procedures }\end{array}$ \\
\hline $\begin{array}{l}\text { During a } \\
\text { task }\end{array}$ & $\begin{array}{l}\text { Time pressure (in tasks on avoiding } \\
\text { threats) }\end{array}$ \\
\hline Post-task & $\begin{array}{l}\text { Learner's report } \\
\text { Repeat the task }\end{array}$ \\
\hline
\end{tabular}

Source: On the basis of Ellis (2006).

This universal pattern of a lesson supported the collaborative work. This work resulted in series of machinima on posttraumatic stress disorder, which can be used for storytelling activities or transmedia learning.

\section{CONCLUSION AND IMPLICATIONS}

The presented case studies proved that machinima can be a versatile tool in education for security and safety. Machinima as a digital video can be used as lead-in tool, for review and follow-up, discussion, storytelling, predictions, and other activities designed by a teacher. However, this kind of video may not be attractive for some students and choosing machinima for the lesson should be preceded by asking about students' preferences.

Machinima as a task-based approach bring a great value for individual and group projects on education for safety and security. E.g. recording simulations allows students for gaining knowledge on how to perform in face of threats or dangers. Furthermore, students who are engaged in the production process improve social skills, they negotiate, mediate and solve problems. The development of interpersonal skills can be greater when they collaborate in international environment (multicultural interactions). Machinima creation helps students develop digital skills, and triggers their creativity. Due to their engagement in the learning process they memorize the topic better and perceive a lesson as more attractive.

Working with machinima (perceived as a task) is also related with some requirements. It should be noted that poor IT infrastucture, weak internet connection, and lack of digital skills either students or a teacher may cause an educational failure. Students can be discouraged and treat this kind of activity as unattractive and redundant. Sometimes the group or a teacher may simply not like this kind of activity.

Future actions concerning the application machinima in educational process should be based on the training needs analysis, which involves students and also teachers' preferences as the strongest motivation is that of the satisfaction resulting from the activity with students (Serbanescu, 2013).

\section{REFERENCES}

[1]. Ellis, R. The Methodology of Task-Based Teaching, Asian EFL Journal, 8(3)/2006.

[2]. Fei, D., \&Anbi, Y. (2011). Safety education based on virtual mine. Procedia Engineering, 26, 1922-1926.

[3]. Klein, R. A. (2016). Safety, Security, Health and Social Responsibility. In Cruise Business Development (pp. 3-15). Springer International Publishing.

[4]. Kelland, M., Morris, D., \& Lloyd D. (2005). Machinima: Making Movies in 3D Virtual Environments. Cambridge: The Ilex Press.

[5]. Krapp, P. (2010). Machinima: of Games and Gestures. In: M. Nitsche\& H. Lowood (Eds.), The Machinima Reader. MIT Press.

[6]. Kunikowski, J. (2000). Uwarunkowania procesu edukacji dla bezpieczeństwa. Wydawnictwo Uniwersytet Przyrodniczo-Humanistyczny w Siedlcach Instytut Pedagogiki, Siedlce [in Polish].

[7]. Le, Q. T., \& Park, C. S. (2012, August). Construction safety education model based on second life. In Teaching, Assessment and Learning for Engineering (TALE), 2012 IEEE International Conference on (pp. H2C-1). IEEE.

[8]. Maciejewski, P., Żuber, M., Ulewicz, M., \&Sobianowska, K. (2009). Removal of radioisotopes from waste waterafter" dirty bomb" decontamination.

[9]. Maciejewski, P., Robak, W., \& Młynarczyk, M. (2015). Protection from CBRN Contamination in the PolishArmedForces. Bezpieczenstwo i Technika Pozarnicza, 37, 107-118.

[10]. Marino, P. (2004). The art of machinima: 3D gamebased filmmaking. Scottsdale: ParaglyphPress.

[11]. Nijs, M. M., Clothilde, J., Bun, E., Tempelaar, W. M., de Wit, N. J., Burger, H., ... \&Boks, M. (2014). Perceived school safety is strongly associated with adolescent mental health problems. Community mental health journal, 50(2), 127.

[12]. Nikula, T., \&Dafouz, E. (Eds.). (2016). Conceptualisingintegration in CLIL and multilingualeducation (Vol. 101). MultilingualMatters.

[13]. Pich, R., Maciejewski, P., Wrzesiński, J. (2011). Casualtiestrafficorganizationduring mass decontamination. Bezpieczeństwo i Technika Pożarnicza, 23.

[14]. Poland ADL Partnership Lab website http://adl.aon.edu.pl/aktualnosci/deep-ukraine$\operatorname{adl}(30.06 .2017)$.

[15]. Penzenstadler, B., Raturi, A., Richardson, D., \& Tomlinson, B. (2014). Safety, security, now sustainability: The nonfunctional requirement for the 21 st century. IEEE software, 31(3), 40-47.

[16]. Pieczywok, A. (2012). Edukacja dla bezpieczeństwa wobec zagrożeń $i$ wyzwań wspólczesności. Wydawnictwo Akademia Obrony Narodowej, Warsaw. [In Polish].

[17]. Razzaque, M. A., \& Clarke, S. (2015, December). A security-aware safety management framework for IoTintegrated bikes. In Internet of Things (WF-IoT), 2015 IEEE 2nd World Forum on (pp. 92-97). IEEE.

[18]. Regulation of the Minister of National Education of 28 August, 2009 on the implementation of safety and security education, OJ Of 2009 No. 139 pos. 1131, http://prawo.legeo.pl/prawo/rozporzadzenie-ministra- 
edukacji-narodowej-z-dnia-28-sierpnia-2009-r-w-sprawiesposobu-realizacji-edukacji-dla-

bezpieczenstwa/(30.06.2017).[In Polish].

[19]. Robinson-Mallett, C., Kaiser, B., \& Meyer, J. (2015). Safety and Security for Networked Vehicles. Auto Tech Review, 4(5), 40-43.

[20]. Şerbănescu, L. (2013). The relationshipbetween the motivation to attend the teachereducationprogramme and the acquisition of professionalcompetences. The case of Romanianteachers. Procedia-Social and BehavioralSciences, 76, 770-774.

[21]. Schneider, C. (2016). Learning languages in 3D worlds with Machinima. CALL communities and culture-short papers from EUROCALL 2016 Edited by SalomiPapadimaSophocleous, Linda Bradley, and Sylvie Thouësny, 418-432. [22]. Siuda, T. (2001). Edukacja dla bezpieczeństwa w wybranych czasopismach, [In].: Edukacja do bezpieczeństwa $i$ pokoju $w$ obliczu wyzwań XXI wieku. Edukacja do bezpieczeństwa pokoju i praw człowieka. Part 2. Wydawnictwo Akademii Podlaskiej, Siedlce, p. 116-117. [In Polish].

[23]. Sobianowska-Turek, A., Szczepaniak, W., Sobianowska, K., \& Maciejewski, P. (2015). Recovery of K, $\mathrm{Na}, \mathrm{Mn}$ and $\mathrm{Zn}$ from spentbatteries by leaching with water. Przemysl Chemiczny, 94(5), 702-705.

[24]. Sobianowska-Turek, A., Szczepaniak, W., Maciejewski, P., \& Gawlik-Kobylińska, M. (2016). Recovery of zinc and manganese, and othermetals ( $\mathrm{Fe}, \mathrm{Cu}$, $\mathrm{Ni}, \mathrm{Co}, \mathrm{Cd}, \mathrm{Cr}, \mathrm{Na}, \mathrm{K}$ ) from Zn-MnO 2 and $\mathrm{Zn}-\mathrm{C}$ waste batteries: Hydroxyl and carbonate co-precipitation from solutionafterreducingacidicleaching with use of oxalicacid. Journal of Power Sources, 325, 220-228.

[25]. Ulewicz, M., Maciejewski, P., Robak, W., Wrzesinski, J. A., \& Rakowska, J. (2013). The economy of waste small-sizebatteries and accumulators. ChemicalIndustryPrzemysl Chemiczny, 92(2), 1000-1008.

[26]. Weerasinghe, A., \&Mathews, M. (2017). SupportingConstructive Video-Based Learning: RequirementsElicitation from ExploratoryStudies. In ArtificialIntelligence in Education (p. 224). Springer.

[27]. Węsierski, T., Gałązkowski, R., \&Zboina, J. (2013). Rescue operations in case of chemical hazards. Bezpieczenstwo i TechnikaPozarnicza, 29, 19-27

[28]. Zhao, D., \& Ye, Y. (2012). Using virtual environments simulation to improve construction safety: an application of 3d online-game based training. Future Control and Automation, 269-277.

\section{BIOGRAPHY}

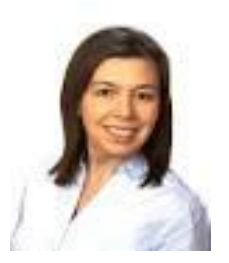

Assistant Professor at the War Studies University in Warsaw, Poland. Interested in emerging technologies in education and training.
Assistant Professor at the War

Studies University in Warsaw, Poland. Interested in emerging technologies in education and training. 